\title{
trrabalnânecessário
}

issn: $1808-799 \mathrm{X}$

ano 7 - número 9 - 2009

\section{Algumas iniciativas em torno do resgate e preservação da memória do CEFET Celso Suckow da Fonseca}

Zuleide Simas da Silveira ${ }^{1}$ - zuleidesilveira@terra.com.br

\begin{abstract}
Nos nossos dias, já ninguém duvida de que a história do mundo deve ser reescrita de tempos em tempos. Esta necessidade não decorre, contudo, da descoberta de numerosos fatos até então desconhecidos, mas do nascimento de opiniões novas, do fato de que, o companheiro do tempo que corre para a foz, chega a pontos de vista de onde pode deitar um olhar novo sobre o passado... $(\text { GOETHE) })^{2}$.
\end{abstract}

\section{Considerações iniciais}

Nos estudos de Maurice Halbwachs, a memória é, não apenas, autobiográfica e pessoal, mas também, influenciada pelo meio social, sendo, por conseguinte, uma construção social, um fenômeno coletivo ${ }^{3}$. Do mesmo modo, as lembranças sobre acontecimentos e fatos históricos se fortificam em virtude de narrativas coletivas, ou, de comemorações que resultam do trabalho de um grupo de pessoas que se debruce sobre a construção de uma determinada memória coletiva, ou, ainda, de "lugares de memória"4.

Elemento de coesão social, a memória tem se constituído em um projeto tenso e contraditório. Se por um lado, a memória permite uma visão retrospectiva do passado com vistas à reconstrução histórica de uma trajetória de vida, ou de acontecimentos, ou, de uma instituição; de outro, tem sido objeto de manipulações de ordem política e ideológica, que se referem à negação de fatos históricos, se materializando, em muitas circunstâncias, não no esquecimento, mas, sim, no 


\section{trrabalnânecessário}

issn: $1808-799 \mathrm{X}$

ano 7 - número 9 - 2009

silêncio: uma ação intencional e deliberada de apagamento da memória. "Em muitos casos, porém, impõe-se institucionalmente uma determinada versão $\square$ pública, dominante, oficial $\square$ da memória coletiva, a qual pode, então, servir de base à hegemonia de determinado grupo" (CARDOSO, 2005, p.18).

É fato que, a tentativa de manipular a memória é uma realidade, no entanto, o passado está dotado de firme consistência baseada em documentos textuais, iconográficos e peças, não se dobrando às manobras de falseamento da realidade e de livre reconstrução dos fatos. Sendo o presente resultado de um processo histórico e os acontecimentos do passado reconstruídos nesse presente e nele ancorados, a História vai ao encontro da memória na busca da verdade.

Neste ano de 2009, em que se comemora o centenário da Rede Federal de Educação Profissional, Científica e Tecnológica, é, também, momento de confraternização, trocar conhecimento, compartilhar experiências, mas, sobretudo, resgatar a trajetória histórica das instituições que compõem a Rede e de homens, mulheres e jovens que construíram, cotidianamente, suas histórias entrelaçadas a dessas Escolas. É, pois, tempo de resgatar a memória.

Este texto, não tem a ambição de varrer a longa e rica História da Rede, pretende, tão somente, trazer alguns elementos para a reflexão sobre a importância, o significado e a finalidade do trabalho de resgate, preservação e divulgação da memória de uma instituição de ensino. Ao recuperar a sucessão de iniciativas em torno do trabalho de resgate e preservação da memória do CEFET/RJ, desvela que tal processo de trabalho se constitui em quadro tenso e contraditório.

\section{Breves palavras sobre a história do CEFET/RJ}

O CEFET/RJ, reconhecido historicamente e socialmente entre instituições de ensino do Estado do Rio de Janeiro e do país é formado por sua unidade-sede, campus Maracanã e quatro Unidades de Ensino: na zona norte do município do Rio 


\section{trabalnonecessário}

issn: $1808-799 \mathrm{X}$

ano 7 - número 9 - 2009

de Janeiro (UnED Maria da Graça); na Baixada Fluminense (UnED Nova Iguaçu); na cidade de Petrópolis (UnED Petrópolis); no município de Nova Friburgo (UnED Nova Friburgo); e na região da Costa Verde (UnED Itaguaí), destacando-se por prestar a população uma educação pública de qualidade, atuando em vários níveis da educação como: ensino médio, educação profissional de nível técnico, ensino superior. Além disso, possui curso de mestrado, cursos de pós-graduação lato sensu e atividades de pesquisa e de extensão.

A história do Centro Federal de Educação Tecnológica Celso Suckow da Fonseca (CEFET/RJ), está relacionada às transformações econômicas, políticas e sociais pelas quais a sociedade brasileira passou por todo século $X X$ e início do século XXI. Portanto, remonta à origem do ensino profissionalizante no Brasil, quando, em 1909, o Presidente Nilo Peçanha assinou o Decreto n- 7.566, determinando a criação de Escolas de Aprendizes Artífices, destinadas ao ensino profissional gratuito nas capitais dos estados.

Localizado na região metropolitana do Rio de Janeiro, segundo parque industrial do país, a instituição ora denominada CEFET/RJ ${ }^{5}$ inicia suas atividades em 1917, na Escola Normal de Artes e Ofícios Wenceslau Brás, administrada pela Prefeitura Municipal do Distrito Federal. Sua finalidade era preparar mestres e contramestres para estabelecimentos de ensino profissional e formar professores de trabalhos manuais para as escolas primárias. 


\section{frabalnonecessário}

issn: $1808-799 \mathrm{X}$

ano 7 - número 9 - 2009

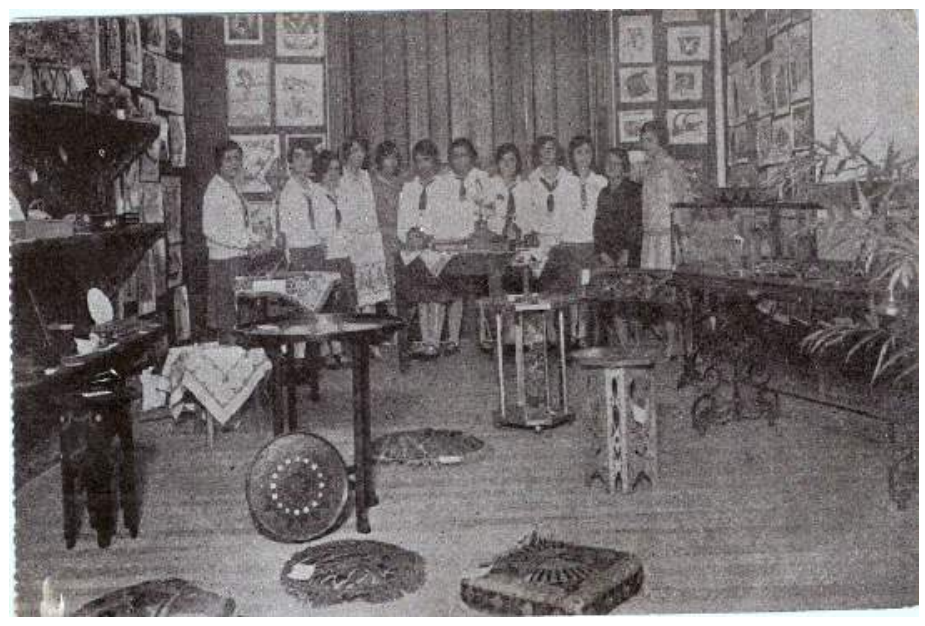

Escola Normal de Artes e Ofícios, 1917 -1937: Exposição anual de trabalhos de Arte Decorativa. Acervo da Seção de Documentação/ Setor de Arquivo do CEFET/RJ. Autor desconhecido.

Em 1937, início do Estado Novo, a Escola Normal de Artes e Ofícios, sob jurisdição do Governo Federal desde 1919, é transformada em liceu industrial destinado ao ensino profissional de todos os ramos e graus, sendo equiparada às Escolas de Aprendizes Artífices mantidas pela União. A Escola Normal de Artes e Ofícios é demolida, iniciando-se a construção do liceu. Antes, porém, que o liceu fosse inaugurado, sua denominação foi mudada, passando a Escola Técnica Nacional (ETN), consoante o espírito da Lei Orgânica do Ensino Industrial, promulgada em 30 de janeiro de 1942. A ETN, instituída pelo Decreto-Lei no 4.127 , de 25 de fevereiro de 1942, que estabeleceu as bases de organização da rede federal de estabelecimentos de ensino industrial, é incumbida de ministrar cursos industriais e de mestria de $1^{\circ}$ ciclo; e cursos técnicos e pedagógicos de $2^{\circ}$ ciclo. 


\section{trabalhonecessário}

issn: $1808-799 \mathrm{X}$

ano 7 - número 9 - 2009

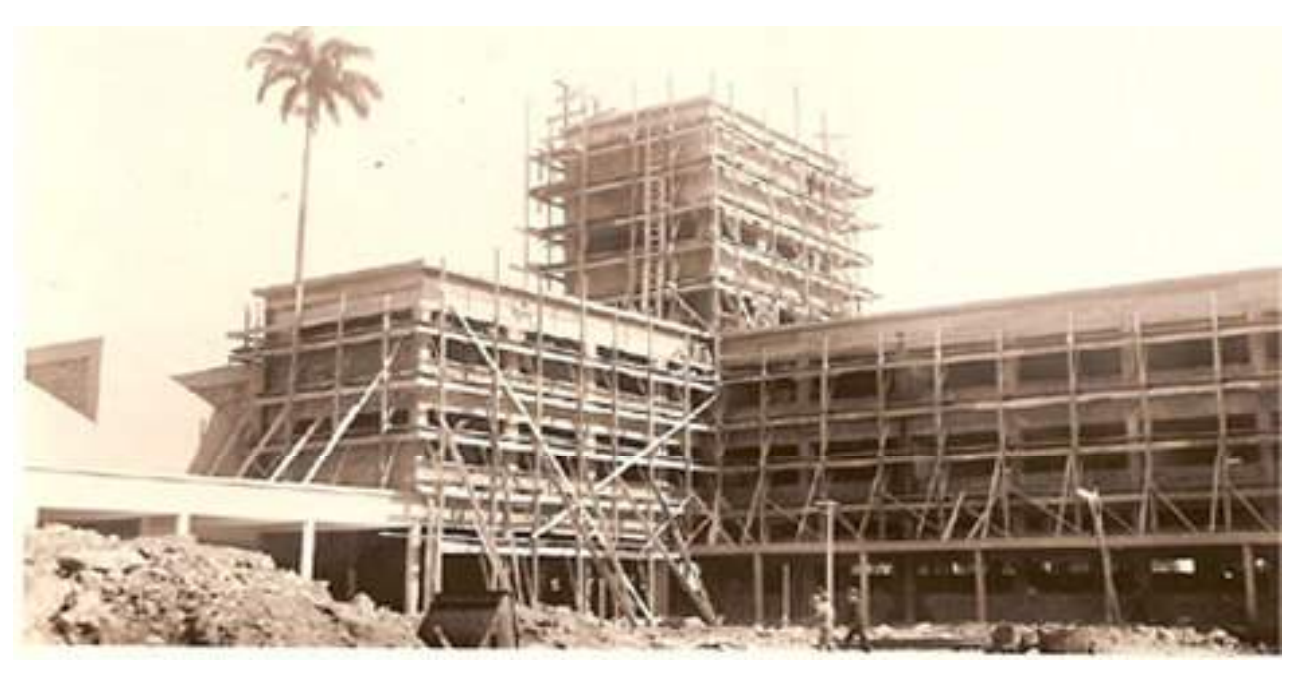

A construção da ETN, 1938. Acervo da Seção de Documentação/Setor de Arquivo do CEFET-RJ, autor desconhecido.

A partir do Decreto n 47.038, de 16 de outubro de 1959, a instituição adquire maior autonomia administrativa, passando, gradativamente, a extinguir os ginásios industriais - cursos de $1^{\circ}$ ciclo - e atuar na formação exclusiva de técnicos. Em 1966, em plena ditadura militar, são implantados os cursos de Engenharia de Operação, introduzindo-se, assim, a formação de profissionais para a indústria em cursos de nível superior de curta duração. Os cursos eram realizados em convênio com a Universidade Federal do Rio de Janeiro, para efeito de colaboração do corpo docente e expedição de diplomas. A necessidade de preparar professores para lecionar as disciplinas específicas dos cursos técnicos e dos cursos de Engenharia de Operação levou, em 1971, à criação do Centro de Treinamento de Professores, funcionando em convênio com o Centro de Treinamento do Estado da Guanabara (Ceteg) e o Centro Nacional de Formação Profissional (Cenafor).

Em 1978, com a transformação da Escola Técnica Federal (ETF) em Centro Federal de Educação Tecnológica, o CEFET/RJ, em conformidade com a lei que o criou, eleva-se ao status de instituições de educação superior, devendo atuar como 


\section{traoalnonecessário}

issn: $1808-799 \mathrm{X}$

ano 7 - número 9 - 2009

autarquia de regime especial, vinculada ao Ministério da Educação e Cultura (MEC) ${ }^{6}$ - detentora de autonomia administrativa, patrimonial, financeira, didática e disciplinar - , na oferta de cursos de graduação e pós-graduação, em atividades de extensão e na realização de pesquisas na área tecnológica. A finalidade da lei que criou os Cefets foi a de verticalizar; promover a intercomplementaridade e continuidade do ensino técnico no ensino superior; orientar sua atuação, de forma a dotá-los de identidade própria, diferenciando-os das universidades. Para tal, o CEFET/RJ levou um período de, aproximadamente, quatro anos para adaptar-se ao novo estatuto e, elaborar seu organograma e regimento interno.

Os Centros Federais de Educação Tecnológica inauguram, no país, um novo modelo de formação profissional, tecnólogos ${ }^{7}$ (em cursos de curta duração) e, engenheiros industriais (em cursos com igual duração dos cursos de engenharia convencionais). A partir daí, fica estabelecida a política diretriz de ações futuras do MEC.

No cenário nacional o milagre econômico dava sinais de esgotamento. Ocorre alta dos preços de produtos importados, explosão dos juros e a derrocada dos preços de produtos primários exportados pelo país, o que provoca a retração de ações por parte do MEC até o final da primeira metade dos anos de 1980. Nesta década o modelo CEFET é reconhecido como "válido e eficaz".

A partir dos anos de 1990, a educação tecnológica pode ser conceituada como uma educação moderna, capaz de acompanhar o desenvolvimento das forças produtivas e, devendo, por conseguinte, aproximar-se do mercado ${ }^{8}$.

Para atender as demandas impostas à nova educação, no âmbito do MEC, inicia-se uma reforma administrativa com a criação da Secretaria Nacional de Educação Tecnológica (Senet), posteriormente Secretaria Nacional de Educação Média e Tecnológica $\left(\operatorname{Semtec}^{9}\right.$ ). A consolidação do modelo CEFET, culminou com a institucionalização do Sistema Nacional de Educação Tecnológica e a transformação de todas ETFs em Cefets. 


\section{|เraba|lnanecessário}

issn: $1808-799 \mathrm{X}$

ano 7 - número 9 - 2009

No Governo Fernando Henrique Cardoso, o CEFET/RJ passa por mudanças significativas. Seguindo os princípios neoliberais relacionados às políticas públicas de educação, o governo central promove a reforma do ensino médio e técnico no Brasil, na qual foram utilizados vários instrumentos legais, tais como: o Decreto $\mathrm{n}^{\circ}$ 2.208/97, a Portaria do MEC n 646/97 e a Portaria do MEC nำ1005/97. O Decreto no 2.208 , de 17 de abril de 1997 - regulamentador do $\S 20$ do art. 36 e dos arts. 39 a 42 da nova LDB - estabeleceu que "a educação profissional de nível técnico terá organização curricular própria e independente do ensino médio, podendo ser oferecida de forma concomitante ou seqüencial a este"(artigo $5^{\circ}$ ). Deste modo, os cursos técnicos de nível médio, que até então eram oferecidos de forma integrada, passam, a partir de 1998, a funcionar em dois segmentos distintos: ensino médio e educação profissional de nível técnico.

No mandato de Luiz Inácio Lula da Silva é exarado o Decreto no 5.154 de 23 de julho de 2004 - revogador do Decreto $n^{\circ}$ 2. 208/97 - que retorna à LDB e renova a regulamentação do $\S 2^{\circ}$ do art. 36 e os arts. 39 a 41 da Lei $n^{\circ} 9.394 / 96$. Se de um lado, o Decreto ํㅡㄴ 208/97 representa a vitória de forças conservadoras, em determinado período histórico; de outro, Decreto no 5.154/04 acomoda a correlação de forças, facultando às instituições de ensino o oferecimento da educação profissional técnica de nível médio articulada com o ensino médio, de forma integrada. Decorridos mais de cinco anos da promulgação do Decreto n- 5.154/04, o CEFET/RJ, sequer avançou na discussão coletiva sobre a proposta de integração do ensino médio e técnico.

No ano de 2005, por meio da .Lei no 11.195 , ocorre o lançamento da primeira fase do Plano de Expansão da Rede Federal de Educação Profissional e Tecnológica, com a construção de 64 novas unidades de ensino. Ainda em 2005, o CEFET do Paraná é transformado em Universidade Tecnológica Federal do Paraná (UFTPR).

Já o lançamento da segunda fase do Plano de Expansão da Rede, tendo como meta inaugurar mais 150 unidades, perfazendo um total de 354 unidades, até 


\section{trabalnonecessário}

issn: $1808-799 \mathrm{X}$

ano 7 - número 9 - 2009

o final do mandato de Lula da Silva, ocorreu no ano de 2007. Neste contexto, o CEFET/RJ expandiu-se academicamente e em área física. Atualmente, além da oferta regular de cursos de ensino médio e de educação profissional técnica de nível médio, o CEFET/RJ oferece dez cursos no nível da educação superior (superiores de tecnologia e bacharelado), cinco cursos de pós-graduação lato senso, outros cinco de pós-graduação strictu (cursos de mestrado), além de atividades de pesquisa e de extensão, incluídos.

Fachada principal, 2006. Acervo da Seção de Documentação/

Setor de Arquivo do CEFET/RJ, autor Jânio de Carvalho.

Ainda no ano de 2007, o Decreto № 6095 de 24 de abril estabelece as diretrizes para reorganização e integração de institutos federais de educação tecnológica, com vistas à criação dos Institutos Federais de Educação, Ciência e Tecnologia (IFET), no âmbito da Rede Federal de Educação Tecnológica.

E, em dezembro de 2008, os CEFETs são transformados, em bloco, à exceção do CEFET/RJ e CEFET/MG, em Institutos Federais de Educação, Ciência e 


\section{traoalnonecessário}

issn: $1808-799 \mathrm{X}$

ano 7 - número 9 - 2009

Tecnologia, quando se institui a Rede Federal de Educação Profissional, Científica e Tecnológica, constituída pela UT, CEFETs e IFETs.

Os Institutos Federais são instituições de educação superior, básica e profissional, pluricurriculares e multicampi especializados na oferta de Educação profissional e tecnológica nas diferentes modalidades de ensino, com base na conjugação de conhecimentos técnicos e tecnológicos com as suas práticas pedagógicas, nos termos desta Lei (Lei no 11.892, de 29/12/2008).

Em uma fase em que instituições da rede federal de educação profissional, científica e tecnológica passam por uma série de transformações, quer em seus quadros, quer em seus estatutos e regimentos, quer em seus planos de carreira e salários, é de fundamental importância que se forme um grupo de trabalho orgânico, que se volte à implantação, de fato e de direito, de um núcleo de memória com vistas a resgatar, preservar, pesquisar e divulgar a história da instituição.

Ressalte-se, desde já, que o trabalho daqueles que se reúnem em torno de um núcleo de memória, não se limita às atividades arquivísticas. Enquanto, a ocupação arquivística visa à organização dos arquivos, por meio do incremento de atividades de tratamento técnico dos documentos, como avaliar, classificar, ordenar, descrever, acondicionar e programar medidas de alteração de suporte físico para a preservação e para o acesso; o núcleo de memória volta-se para pesquisas em acervo próprio e, ou, em convênio com outras instituições, com vistas a organizar e promover eventos de ordem acadêmica, como seminários, conferências, exposições, além de publicar a memória institucional em artigos, livros, e produzir documentários em meios impresso, magnético e Internet, de modo a mobilizar elementos de reconhecimento da identidade institucional e daqueles que cotidianamente constroem a história da instituição.

Com isto, queremos afirmar que o trabalho de um núcleo de memória não se confunde com o de um setor de arquivo. Entretanto, há que se destacar que não são duas esferas de ação que se excluem mutuamente, ao contrário, são 


\section{trabalnonecessário}

issn: $1808-799 \mathrm{X}$

ano 7 - número 9 - 2009

complementares, alias, um núcleo de memória, somente, se sustenta, abastecido, continuamente, pelo setor de arquivo da documentação institucional, sem o que, estará fadado ao fracasso. Ao mesmo tempo, o setor de arquivo se alimenta do fluxo de documentação produzido pelo núcleo de memória.

\section{Resgate e preservação da memória do CEFET/RJ: um processo marcado por continuidade e rupturas}

$\mathrm{O}$ acervo do CEFET/RJ é constituído de rica documentação que data desde o início de suas atividades com a criação da Escola Normal de Artes e Ofícios Wenceslau Braz, em 1917, até os dias atuais. Essa documentação registra diversas etapas da história da instituição, tanto no aspecto institucional, acadêmico, quanto no aspecto físico, estando organizada, fundamentalmente, em cinco fundos, segundo cortes histórico-cronológicos: Escola Normal de Artes e Ofícios Wenceslau Braz (1918-1937); Escola Técnica Nacional (1942-1965); Escola Técnica Federal da Guanabara (1965-1967); Escola Técnica Federal Celso Suckow da Fonseca (19671978); Centro Federal de Educação Tecnológica Celso Suckow da Fonseca, a partir de 1978. documentação/Setor de Arquivo do CEFET/RJ, autor desconhecido. 


\section{traoalnonecessário}

issn: $1808-799 \mathrm{X}$

ano 7 - número 9 - 2009

Fonte primária para a história da educação profissional no Brasil, a Seção de Documentação/Setor de Arquivo Geral do CEFET/RJ está localizado no bloco L da unidade-sede - campus Maracanã - e possui, aproximadamente, dois milhões e quinhentos mil documentos de alunos e novecentos mil documentos históricoadministrativos; uma coleção de, aproximadamente, quatro mil fotografias, sendo que duas mil em suporte de papel, e outras tantas em meio digital; seiscentas fitas de vídeo, formato U-Matic e VHS/SVHSU, algumas identificadas e outras, em processo de identificação; trinta e cinco Mini-DV identificados; material informativo como jornais e boletins; peças de mobiliário, fabricado na instituição, em sua primeira fase de atividade (1918-1937); trabalhos de alunos tais como vasos de cerâmica, peças de bordado e costura; máquina de datilografia que data, aproximadamente, a década de 1940; e, ainda, algumas peças usadas em aulas de laboratórios, como balanças e instrumentos de medidas elétricas; uniformes de alunos; bandeiras e flâmulas.

Ressalte-se, que desde a primeira metade dos anos de 1990, o CEFET/RJ, por meio do Setor de Arquivo, vem organizando, catalogando e identificando a documentação textual produzida ao longo de sua história. Encontra-se em fase de elaboração os inventários da Escola Normal de Artes e Ofícios Wenceslau Braz (1917 - 1937) e da Escola Técnica Nacional (1942 - 1965).

Até o início dos anos de 1990, a iniciativa de organização do arquivo de documentos textuais foi de Neuza Monteiro, técnica-administrativa, função datilógrafa, ex-aluna do curso de Chapéus e Ornatos, da Escola Técnica Nacional. Nesse tempo, a professora Dina Luiz Garcia, da disciplina de Organização Social e Política do Brasil (OSPB), ex-aluna do Curso de Desenho e Arquitetura de Móveis, da Escola Técnica Nacional, encarregou-se de promover exposições de peças museológicas. 


\section{traoalnonecessário}

issn: $1808-799 \mathrm{X}$

ano 7 - número 9 - 2009

O arquivo não era voltado para preservação da história da escola. Funcionava, apenas, para alimentar informações referentes ao corpo discente. Ademais, o descarte de documentos textuais, objetos e livros, publicados no setor de reprografia da escola, foi realizado por comissões com o objetivo de "esvaziar o arquivo", ocasionando perdas significativas e irreparáveis de documentos de valor histórico e administrativo.

Entrementes, ao longo de quase toda década de 1970, o Estudo documentário e histórico sobre a Escola Técnica Federal "Celso Suckow da Fonseca", empreendido pelo Professor de História, Demósthenes de Oliveira Dias, publicado em maio de 1980, na gestão do Professor Edmar de Oliveira Gonçalves, tornou-se referência para todos aqueles que se interessem sobre a história da instituição. Desde a ocupação do Palacete Leopoldina pela Escola Normal de Artes e Ofícios Wenceslau Braz, passando por sua demolição no ano de 1937, pela construção da Escola Técnica Nacional, entre os anos de 1937 e 1942, esmiuçando o início de suas atividades e a inauguração, o historiador desvela as modificações sofridas pela instituição tanto em sua estrutura física, quanto em sua denominação, bem como no plano educacional, até os anos de 1970.

No ano de 1993, foi nomeada uma comissão com a finalidade de por em prática o Projeto Memória Viva, coordenado por Sinclair Guimarães Cechiene, técnico em assuntos educacionais, e Florence Fernandes Bonfim, professora de Educação Artística, substituída, mais tarde, por Marisa Brandão, professora, à época, da disciplina de OSPB, hoje, professora de Sociologia.

No ano seguinte, a instituição recebeu duas servidoras, Maria Alice da Silva e Vera Lúcia de Oliveira Firmo, arquivologitas, que, também, por iniciativa própria se incumbiram de implantar e implementar o Setor de Arquivo, com apoio técnicojurídico do Arquivo Nacional. Pode-se afirmar que foi a partir das relações estabelecidas por Maria Alice e Vera Lúcia, tanto na comunidade interna, quanto na comunidade externa, que ocorreu a institucionalização do Setor de Arquivo, isto é, o 


\section{trabalnonecessário}

issn: $1808-799 \mathrm{X}$

ano 7 - número 9 - 2009

referido setor passou a existir no organograma da instituição, possuindo competências e atribuições.

Vale registrar que a partir da gestão (2003-2007) dos Professores Miguel Badenes e Carlos Artexes, Diretor-Geral e Vice-Diretor, respectivamente, a preservação do acervo foi incentivada por iniciativa do Professor Artexes.

No ano de 2006, a nova iniciativa, vinda da direção-geral, foi posta em prática, com a criação do Centro de Memória do CEFET/RJ. Criado pela Portaria $n^{0} 008$ de 5 de janeiro de 2006, do Diretor-Geral, localizado no bloco D do campus Maracanã, mantendo um grupo orgânico em torno do resgate, da preservação e da divulgação da memória, o Centro de Memória esteve em atividade até o mês de agosto de 2007.

Durante a fase de implantação do referido setor, o grupo de trabalho coordenado por mim, Zuleide Simas da Silveira, e constituído, ainda, pelos professores Mário de Souza (substituído em dezembro de 2006 por Tereza Fachada Levy Cardoso), Marli Carloni e pela arquivologista Vera Firmo, realizou diversas atividades com o objetivo de resgatar, preservar, tratar e divulgar o acervo de peças, textual e iconográfico da instituição, estimulando não só a preservação histórica, mas, também, o trabalho de pesquisa na comunidade interna. 


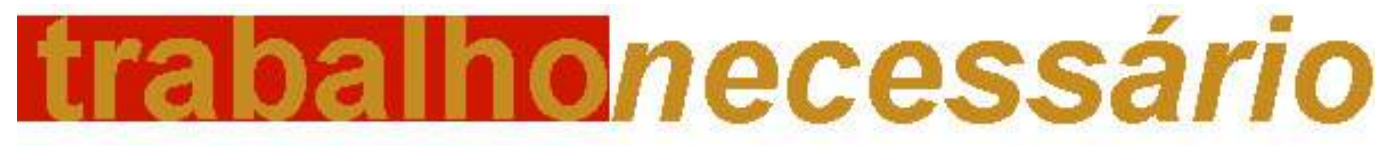

issn: $1808-799 \mathrm{X}$

ano 7 - número 9 - 2009

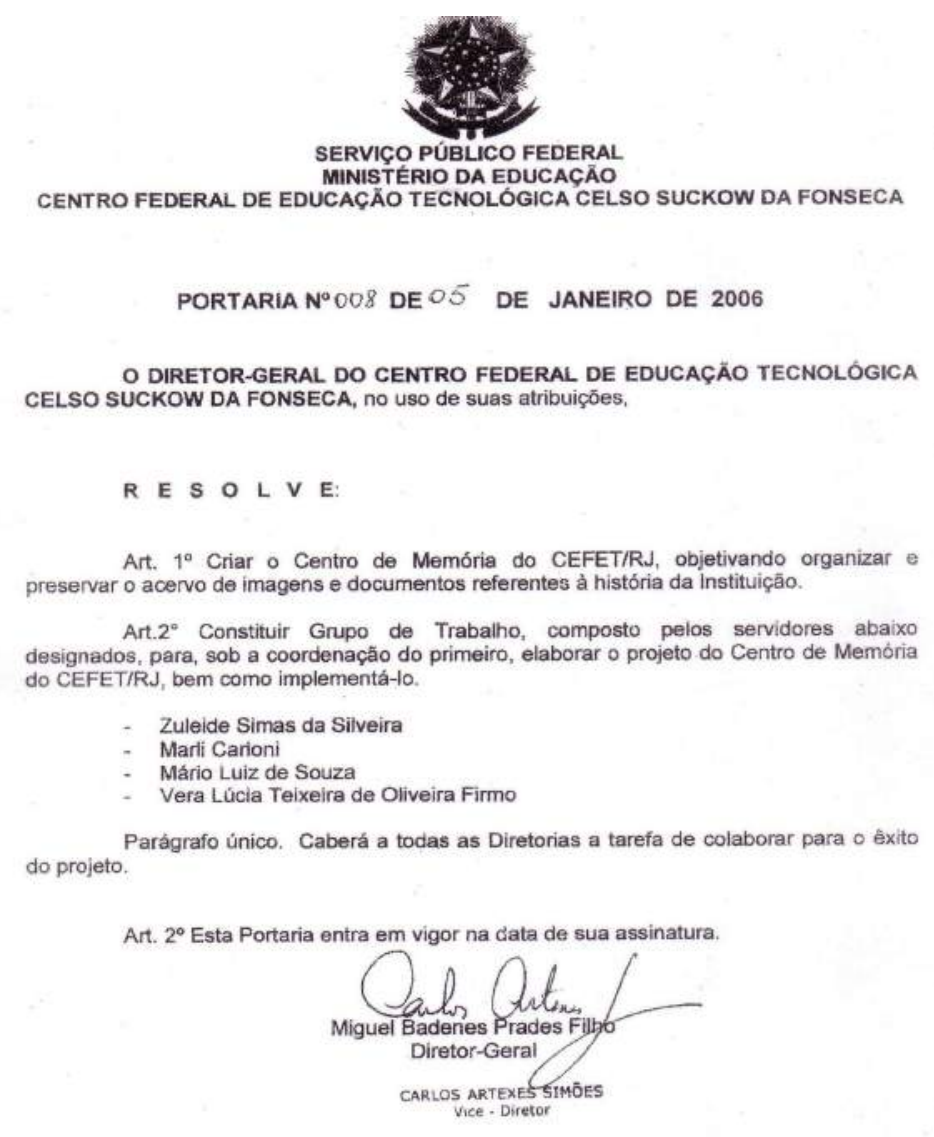

Portaria de criação do Centro de Memória, CEFET/RJ

Além dos servidores nomeados em Portaria para compor o grupo responsável pelo projeto de implantação do Centro de Memória do CEFET/RJ, outros tantos personagens da instituição - entre estagiários, técnicos administrativos, técnicos em assuntos educacionais e professores - comprometeram-se e envolveram-se de modo efetivo com a proposta.

São eles: os estagiários Mário Barreto, Rafael Rodrigo Ferreira, André Gatto, Diego A. Lima e Yasmim Watanabe, da Coordenadoria do Centro de Memória; os técnicos administrativos Edgard Rischter, Luciano Melo, Paulo Costa e Paulo Nassif e, ainda, os estagiários Bruno Santiago e Juliana Moura, todos da Divisão de Mídias Educacionais; os técnicos administrativos Malu D'Aquino e Fernando Bracet, da Seção de Programação Visual; a técnica em assuntos educacionais Vera Leão, da 


\section{traoalnonecessário}

issn: $1808-799 \mathrm{X}$

ano 7 - número 9 - 2009

Divisão de Projetos Educacionais; o professor Salvador Pires, da Coordenadoria de Construção Civil.

Como todo início é difícil, a equipe contou com a consultoria de vários especialistas na área, a exemplo da professora de Arte Geisa Alchorne de Souza (FAETEC), conservadora e restauradora, que, em fevereiro de 2006, ministrou palestra Abordando a conservação e a preservação do acervo institucional; da professora Maria Ciavatta (UFF), doutora em educação, à época, coordenadora do projeto de pesquisa Memória e temporalidades da formação do cidadão produtivo emancipado, que, em março do mesmo ano, promoveu uma manhã de estudos baseada no texto História e imagem: os exemplos da fotografia e do cinema, de Ciro Flamarion Cardoso e Ana Maria Mauad; da professora Maria Cristina Vendrameto (UNICAMP e CEETPS), especialista em arquivologia, que, em abril, palestrou com o grupo, centrando o discurso, não apenas, na figura do orador, mas, sobretudo, com o intuito de troca de experiências, quando se debateu, em condições objetivas, o modo de preservar, tratar e divulgar o acervo histórico, estimulando o trabalho de pesquisa na comunidade cefetiana.

Dando cumprimento às atividades, a equipe do Centro de Memória, em contato com diversos setores da escola, logrou reunir cerca de 4.000 fotografias, que estavam sendo devidamente separadas, classificadas, identificadas e catalogadas, por fundo, consoante a ordem histórico-cronológica e institucional.

Também reuniu algumas peças museológicas que foram apenas identificadas, sem terem sido classificadas e catalogadas, por falta de pessoal e de tempo - peças estas de mobiliário, fabricadas na própria instituição, em sua primeira fase de atividades (1918-1937); diversos trabalhos de alunos, tais como, vasos de cerâmica, bordados e costuras; peças usadas em aulas de laboratórios, como, balanças e instrumentos de medidas elétricas, uniformes de alunos, e, ainda, uma máquina de datilografia datada da década de 1940. 
issn: $1808-799 \mathrm{X}$

ano 7 - número 9 - 2009

Uniforme usado em campeonatos, ano 1952-56.

Acervo da Seção de documentação/Setor de Arquivo do

CEFET-RJ, autor: Zuleide S. Silveira.

Faixa ornamental usada no funeral do patrono da Escola, ano 1966.

Acervo da Seção de documentação/Setor de Arquivo do CEFET/RJ, autor: Zuleide S. Silveira. 


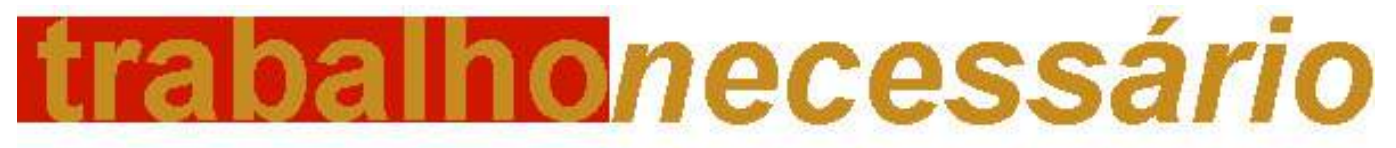

issn: $1808-799 \mathrm{X}$

ano 7 - número 9 - 2009

A arte do entalhe na madeira se articula as linhas retas da produção

voltada para a indústria, ano de 1920-1937. Acervo da Seção de documentação/Setor de Arquivo do CEFET/RJ, autor: Zuleide S. Silveira.

Além disso, a equipe, consciente da importância da preservação do patrimônio histórico do hoje CEFET/RJ, contatou vários profissionais da área de restauração, como, restauradores de papel, de fotografias, de madeira e de tecidos, quando então buscou providenciar a recuperação de algumas peças de tecido e de madeira.

Destaca-se o trabalho de restauração realizado por Helena Lucia Cardoso, conservadora e restauradora, que recuperou uma faixa bordada, medindo $80 \times 10 \times$ $20 \mathrm{~cm}$, em fio metálico, com a inscrição Escola Técnica Nacional; a mortalha de Celso Suckow da Fonseca, de dimensões 4,0 x 1,30 m, de cor púrpura com forro preto, e, ainda, uma cadeira em madeira escura, assento e espaldar revestidos de curvim preto, com acabamento tacheado. 


\section{trabalnonecessário}

issn: $1808-799 \mathrm{X}$

ano 7 - número 9 - 2009

No sentido de divulgar a história da instituição, concedemos entrevista ao jornalista Leonardo Silva, do CECIERJ/CEDERJ, publicada no site www.educacaopublica.ri.gov.br. Afora, a equipe preparou quatro materiais de divulgação da memória institucional, quais sejam: uma coleção de sete banners, medindo $1,20 \times 1,90 \mathrm{~m}$, que deveriam ser instalados no corredor do bloco $A$, no térreo; um livro e um documentário em DVD sob o tema CEFET/RJ seu tempo sua história - 90 anos de ensino profissional; além de inserir um link do Centro de Memória, na home page do CEFET/RJ, retirado do ar por questões de ordem administrativa.

\section{Centra de Memâria da CEFET/RJ}

Anos Protissional

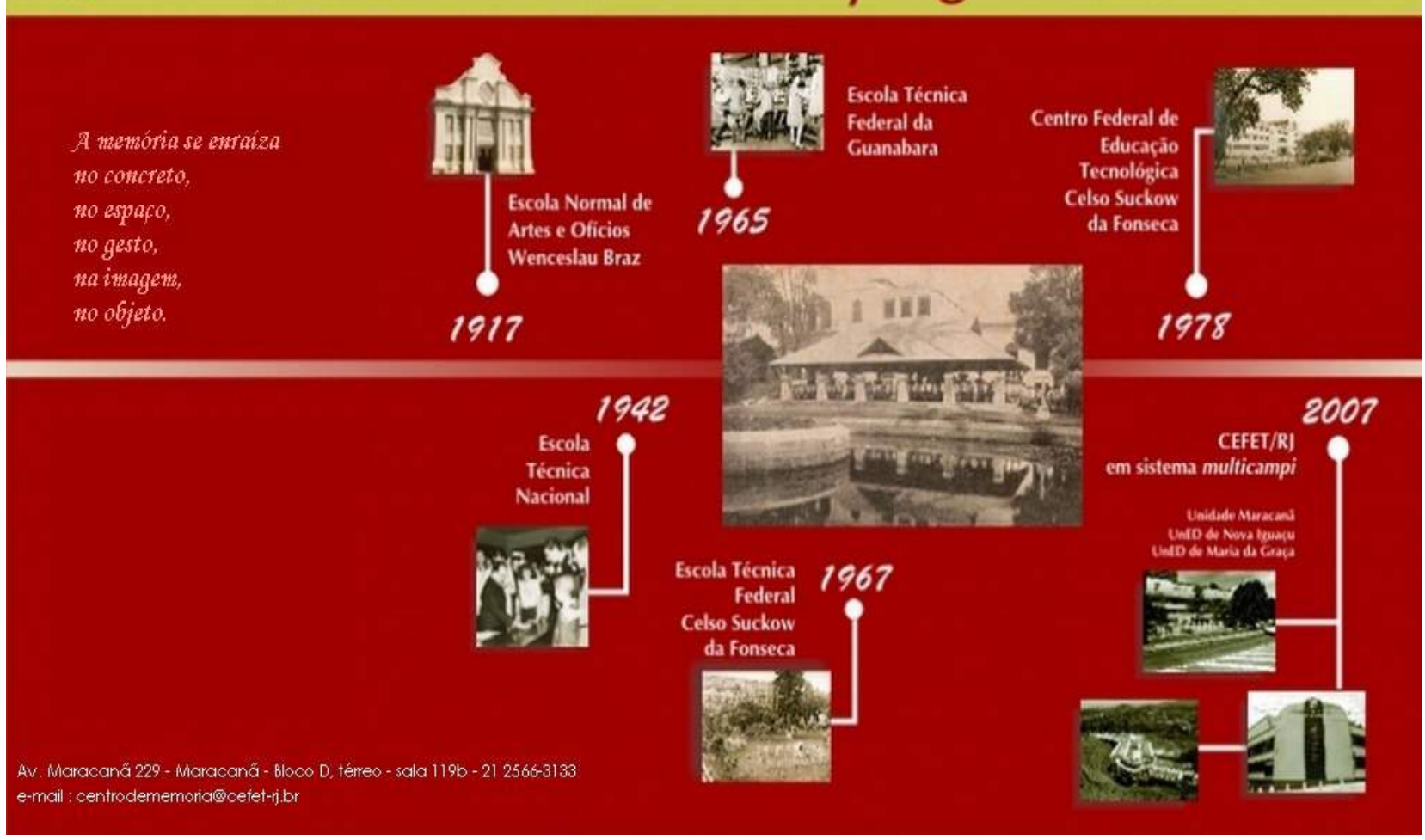

Site do Centro de Memória, ano 2007.

A equipe se empenhou, também, para que a sala de aula A-101 se tornasse espaço reservado ao Museu Escolar, com a finalidade de divulgar e garantir o 


\section{traoalnonecessário}

issn: $1808-799 \mathrm{X}$

ano 7 - número 9 - 2009

acesso do público, em geral, ao acervo da instituição, onde estariam expostos documentos textuais; iconográficos e cartográficos; indumentárias; insígnias; mobílias; objetos de uso pessoal; e, ainda, objetos reunidos por meio de doações.

Tido como espaço físico para fins culturais, se pretendia que o museu, hoje denominado Espaço Histórico-Cultural, atuasse na temática da educação profissional, no Brasil, e suas mostras apresentassem descritivamente, por fundo, a história da instituição desde o início de suas atividades, em 1917, quando Escola Normal de Artes e Ofícios Wenceslau Brás, até os dias que correm.

Além disso, era propósito realizar, também, exposições em homenagem a figuras ilustres que conviveram ativamente com seu tempo e se dedicaram à causa da educação na instituição. Neste sentido, salienta-se o planejamento da exposição que homenagearia o professor Eugenio Trombini Pellerano (1914 - 2006), primeiro professor-pesquisador do CEFET/RJ.

$\mathrm{Na}$ realidade, a proposta de criação do Museu Escolar visava a garantir continuidade e ampliação do trabalho já iniciado pelo Centro de Memória, tornandose um marco diferencial na atuação do CEFET/RJ em relação ao uso, comunicação, documentação, investigação e preservação de seu acervo.

Contudo, em nossa equipe, não contávamos com especialistas, tais como, museólogos e designers, pessoas estas que se responsabilizariam pelo planejamento, produção e montagem da exposição. Assim sendo, além de recorrermos aos profissionais do Museu da República, para nos apoiar nesses aspectos em particular, sugerimos ao professor Miguel Badenes, diretor-geral, o estabelecimento de convênio com uma universidade, no sentido de atender às necessidades do CEFET/RJ, de tal modo que a implementação do Centro de Memória se realizaria interinstitucionalmente. Foi a partir daí que o CEFET/RJ acabou por firmar convênio com a Universidade Federal do Estado do Rio de Janeiro (UNIRIO).

Ao que tudo indica o referido convênio não saiu do papel. O Espaço HistóricoCultural não tem se mostrado como lócus que vise facilitar a construção do 


\section{trabalhonecessário}

issn: $1808-799 \mathrm{X}$

ano 7 - número 9 - 2009

conhecimento da história do CEFET/RJ, por meio de memórias compartilhadas, do patrimônio cefetiano e das relações entre servidores (professores e técnicos administrativos), alunos e ex-alunos, posto que, boa parte do tempo, encontra-se fechado, além de não ter dinamizado, até o momento, exposições temporárias $\square$ um importante veículo de aproximação com a comunidade e de formação cultural. Desde sua inauguração, o Espaço Histórico-Cultural tem mantido a mesma exposição, não desenvolvendo, portanto, um trabalho de visitação com a comunidade interna e externa.

No concernente a atividades de pesquisa, cabe destacar 0 trabalho desenvolvido, desde o ano de 2000, pela professora Tereza Levy Cardoso, com a finalidade de oferecer elementos que possam enriquecer a história do ensino técnico no Brasil, a partir de estudos focados na Escola Normal de Artes e Ofícios Wenceslau Braz, experiência única no país entre 1917 e 1937, período em que deteve o título de escola normal para formar professores habilitados a lecionar nas escolas de aprendizes e artífices.

Nesse sentido, encontra-se em andamento o projeto $A$ formação de professores na Escola Normal de Artes e Ofícios Wenceslau Braz, que conta com bolsistas do Programa Institucional de Bolsas de iniciação Científica do CEFET-RJ, vinculado à Coordenadoria de Pesquisa e Estudos Tecnológicos da Diretoria de Pesquisa e Pós-Graduação (COPET/DIPPG).

Destaca-se, também, o trabalho de pesquisa desenvolvido pelo Professor Alexandre de Carvalho Castro, do Departamento de Administração Industrial, cujo projeto Industrialização, Aptidão, Avaliação: o ensino industrial e a emergência da psicologia aplicada ao trabalho no Brasil, em curso desde 2007, que investiga aspectos históricos relativos ao campo da Psicologia do Trabalho nos fundos Escola Normal de Artes e Ofícios Wenceslau Braz e Escola Técnica Nacional, contando, também, com bolsistas do Programa Institucional de Bolsas de iniciação Científica do CEFET-RJ, vinculado à Coordenadoria de Pesquisa e Estudos Tecnológicos da 


\title{
trabalnonecessário
}

issn: $1808-799 \mathrm{X}$

ano 7 - número 9 - 2009

Diretoria de Pesquisa e Pós-Graduação (COPET/DIPPG), além de bolsistas financiados pelo Edital Ed 062008jovPesq F-B.

Entre outras iniciativas da equipe do centro de memória, salienta-se o encaminhamento à direção-geral, em novembro de 2006, da Proposta para criação do Núcleo de Memória do CEFET/RJ. Tal proposta evidenciava preocupações da equipe, no que tange à necessidade de se manter um grupo orgânico trabalhando em torno da memória e, por conseguinte, da consolidação do trabalho do Centro de Memória, diante do espaço administrativo que vinha ocupando no interior do CEFET/RJ.

\begin{abstract}
A criação do Centro de Memória do CEFET/RJ, pela Portaria no $8 / 06$, do Diretor-Geral, demonstra a vontade política dessa Direção de preservar e garantir o acesso e difusão da memória da Escola; entretanto, não assegura que tal interesse seja garantido em administrações futuras. Em breve pesquisa pela internet, pudemos constatar que a criação de núcleos de memória vem ocupando espaço na cultura de diversas organizações e instituições de pesquisa e ensino do país. Diante desse quadro, o Grupo de Trabalho propõe a criação do Núcleo de Memória do CEFET-RJ, no regimento interno, vinculado diretamente à Direção-Geral (PROPOSTA DE CRIAÇÃO DO NÚCLEO DE MEMÓRIA DO CEFET-RJ, 2006).
\end{abstract}

A extinção do Centro de Memória se deu com a dissolução da equipe de trabalho, por meio da portaria $n^{\circ} 432 / 2007$, do Diretor-Geral, que transferiu a incumbência de resgate, preservação, tratamento e divulgação da memória do CEFET-RJ para a Seção de Documentação/Setor de Arquivo, sob o encargo da arquivista Vera Firmo. 


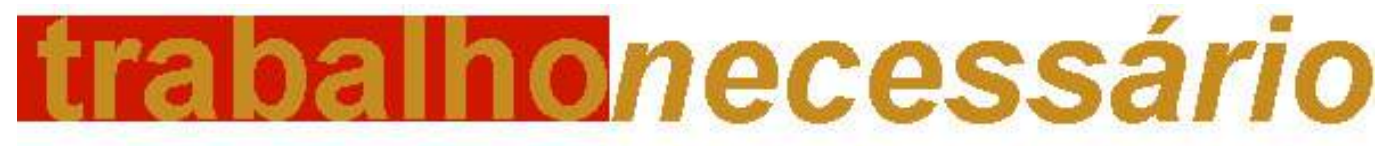

issn: $1808-799 \mathrm{X}$

ano 7 - número 9 - 2009

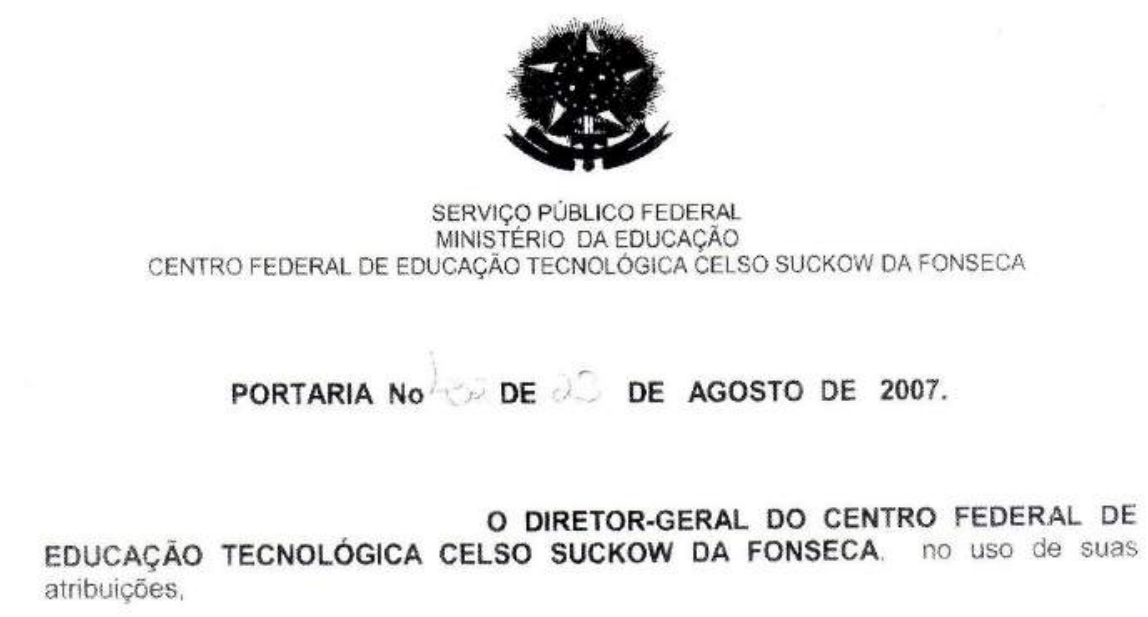

RESOLVE:

Art. $1^{\circ}$ - Revogar a Portaria $n^{\circ} 008$ de 05 de janeiro de 2006 , que constitu! comissão para elaboração de projeto do Centro de Memória.

Art. $2^{\circ}$ - Que o Projeto elaborado pela referida Comissão seja encaminhado à Seção de Documentação do CEFET, objetivando a organizaçăo é preservação do acervo de imagens e documentos da história da instituição.

Art. $3^{\circ}$ - Esta Portaria entra em vigor na data de sua assinatura.

PROF. MIGUEL BADENES PRADES FILHO Diretor-Geral

Portaria de Extinção do Centro de Memória, CEFET/RJ.

A arbitrariedade desse ato acabou por impedir a participação da equipe, tanto na montagem da exposição de inauguração do museu do escolar, quanto do lançamento dos documentários (DVD e livro). Foi assim que em dezembro de 2007, já sob a responsabilidade do Setor de Arquivo, o Espaço Histórico-Cultural foi inaugurado, silenciando-se sobre os nomes daqueles que trabalharam em equipe, organicamente, durante vinte e um meses, contados a partir de janeiro de 2006. 


\section{trrabalnânecessário}

issn: $1808-799 \mathrm{X}$

ano 7 - número 9 - 2009

Inauguração do Espaço Histórico-Cultural, 07/12/2007.

Acervo do Setor de Comunicação do CEFET-RJ, Autor Jânio de Carvalho.

A revogação da Portaria ํo 008/2006 representa um retrocesso no processo de resgate da memória institucional, posto que voltou a se produzir espontaneamente.

Assim sendo, seja por iniciativa própria, seja à convite de outras instituições, a divulgação da memória do CEFET/RJ continua sendo realizada pela autora deste texto e, ainda, pela Professora Tereza Levy Cardoso, por meio de palestras, apresentações em seminários, congressos, etc., utilizando o documentário - livro e DVD - CEFET/RJ seu tempo sua história - 90 anos de ensino profissional.

Em face das repercussões, internas e externas, sobre a extinção do centro de memória, o ano de 2008 foi marcado pelo envolvimento da diretoria na questão da memória institucional.

Primeiro, foi reeditada a obra magna de Celso Suckow da Fonseca, História do ensino industrial no Brasil, sob a coordenação da Professora Carmem Perrotta, Diretora de Gestão Estratégica, em meio magnético (DVD), em alusão aos trinta anos da Lei $n^{\circ}$ 6.545, de 30 de junho, que transformou a antiga Escola Técnica Federal em Centro Federal de Educação Tecnológica, homenageando, assim, não apenas, o autor e sua obra, mas também, aos avanços trazidos pela referida Lei.

Segundo, foi providenciada a restauração do mobiliário que, até o final da década de 1990, compunha o gabinete do diretor-geral, pelo Professor Afonso 


\section{trabalnonecessário}

issn: $1808-799 \mathrm{X}$

ano 7 - número 9 - 2009

Carlos Gomes, assessor do diretor-geral. Encontrando-se em exposição no saguão do campus Maracanã, a mobília, de características contemporâneas do século XIX, é reminiscência da Escola Normal de Artes e Ofícios Wenceslau Braz, composta de dois sofás, mesa retangular com doze cadeiras de madeira de lei, espelheira decorativa com espelho de cristal e armário.

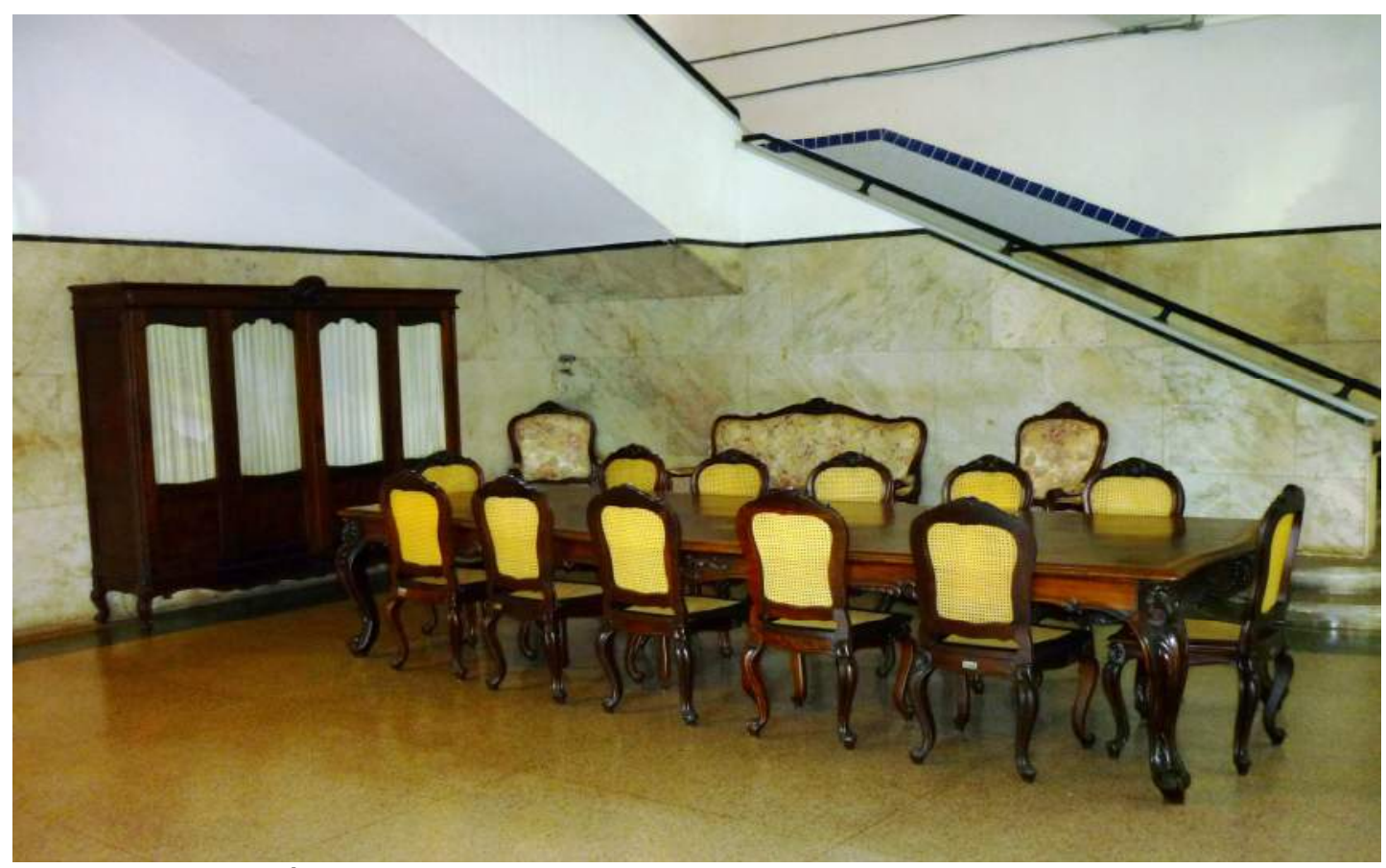

Mobiliário em exposição no saguão do campus Maracanã.

Acervo pessoal de Zuleide Silveira, autor: Zuleide S. Silveira.

No ano de 2009, em 30 de junto, por ocasião do $31^{\circ}$ aniversário da tansformação da ETF em CEFET, foi realizado o Seminário 250 anos de Ensino Público no Brasil - 31 anos de CEFET-RJ, sob iniciativa da Prof Tereza Fachada Levy Cardoso, que contou com o apoio do Departamento de Ensino Médio e Técnico (DEMET) para efeitos de realização e com o suporte do Departamento de Extensão e Assuntos Comunitários (DEAC) para divulgação. Nesse ensejo de comemoração dos 250 nos das reformas pombalinas de educação e dos 92 anos de atividades do CEFET-RJ, o semiário teve como finalidade refletir sobre os dilemas e perpectivas 


\section{trabalnonecessário}

issn: $1808-799 \mathrm{X}$

ano 7 - número 9 - 2009

da educação pública no Brasil, bem como resgatar a história do ensino profissional, tendo como foco a trajetória do CEFET/RJ.

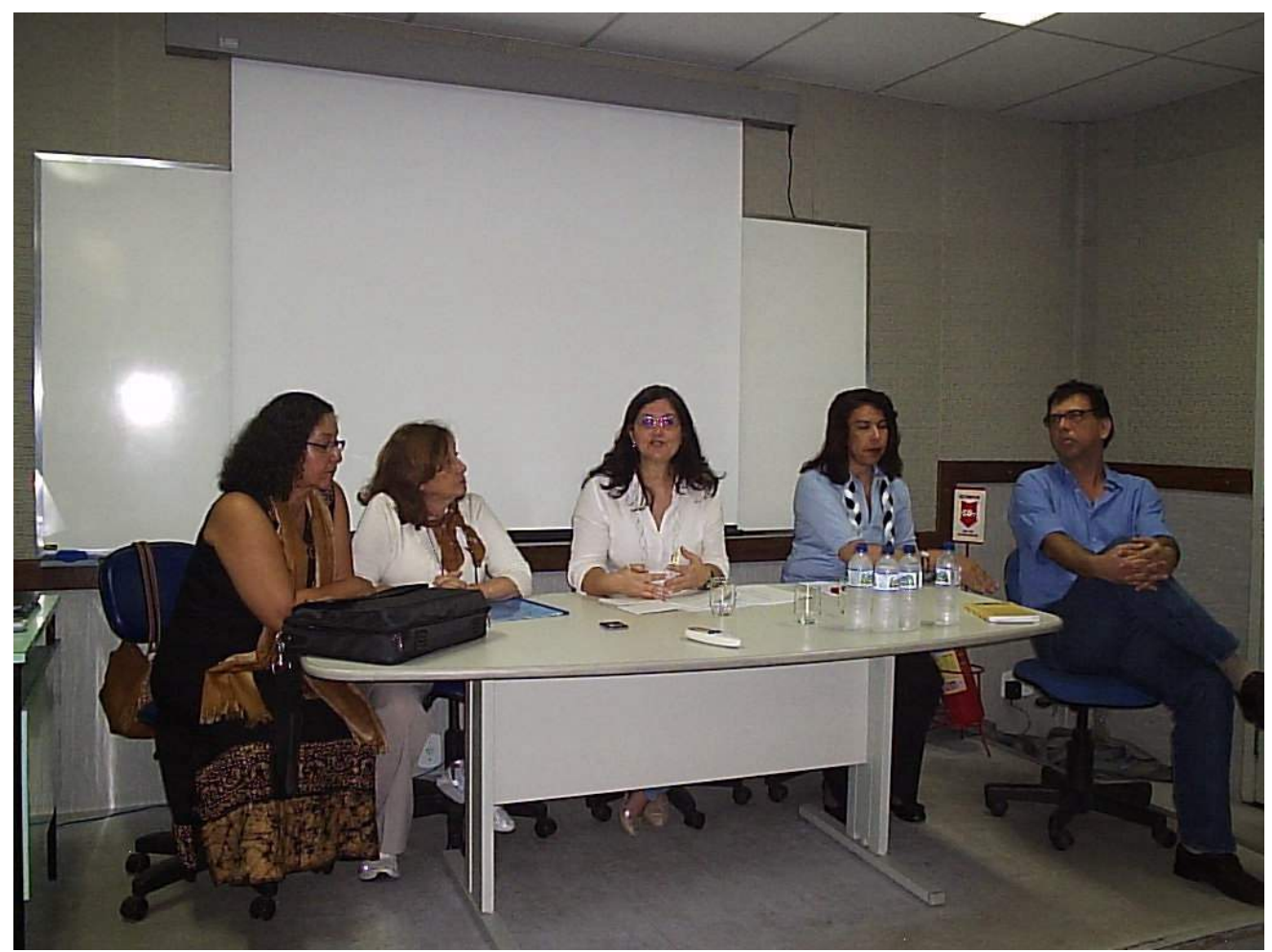

Seminário 250 anos de Ensino Público no Brasil - 31 ano de CEFET/RJ: Mesa $A$ escola pública em perspectiva histórica. Prof. Helena Lemos (SME/RJ); Prof. Mirima Grispun (UERJ); Prof . Tereza Fachada (CEFET-RJ); Prof Zuleide S. Silveira (CEFET/RJ); Prof. Álvaro Senra (CEFET/RJ). Acervo pessoal de Zuleide Silveira, autor Antonio Pithon.

À época da implantação do Centro de Memória do CEFET-RJ, a autora deste texto, cursava o Mestrado em Educação na Universidade Federal Fluminense, tendo como orientadora a Prof ${ }^{\mathrm{a}}$. Dr ${ }^{\mathrm{a}}$. Maria Ciavatta, que como mencionado, anteriormente, coordenava o projeto de pesquisa Memória e temporalidades da formação do cidadão produtivo emancipado - Do ensino médio técnico à educação integrada profissional e tecnológica.

O tema da pesquisa do referido projeto, envolvendo diferentes temporalidades, quer em relação ao tempo, quer em relação ao espaço de pesquisa, quer em relação à transformação do ensino médio técnico no Brasil, analisou o nível 


\section{trabalhonecessário}

issn: $1808-799 \mathrm{X}$

ano 7 - número 9 - 2009

médio e técnico de ensino, por meio, não apenas, de sua historicidade e de processos político-pedagógicos em curso nas escolas de formação técnicoprofissional, mas também, da memória fotográfica.

Neste contexto, tendo como foco a memória da educação profissional no Brasil, debrucei-me sobre a fotografia como fonte histórica, no processo de implantação do Centro de Memória do CEFET-RJ.

Tida como mediação, a fotografia entendida como processo social denso, produzido historicamente, é um mundo "de relações silenciosas, densas congeladas no tempo mínimo do obturador. Mundos de seres calados e imóveis que devem ser decifrados a partir do contexto onde se encontram, na história de sua relação com os demais seres, tanto pessoas quanto objetos" (Ciavatta, 2004, p. 45).

Por ser a fotografia produzida em um determinado contexto e ser parte articulada da totalidade social, sua interpretação requer resgatar "os conceitos de essência e aparência o que permitem fazer a distinção entre o objeto, seu conhecimento imediato e a concepção do conhecimento mediado pelos processos que o constituem" (Ciavatta; Campello, 2006, p.320).

Para se proceder a análise crítica - interpretativa de uma imagem - deve-se partir de três premissas: "a noção de série ou coleção, o princípio de intertextualidade e o trabalho transdisciplinar" (Mauad, 2004, p.19-20).

Foi assim fundamentada, e, segundo critérios adotados pelo Grupo de Pesquisa Memória e temporalidades da formação do cidadão produtivo emancipado para classificação de imagens, que a equipe de trabalho organizou o acervo fotográfico do Centro de Memória do CEFET/RJ.

Apresentam-se, a seguir, os principais passos ou momentos de trabalho.

a) Contato com o acervo fotográfico - A manipulação das fotografias foi iniciada por aquelas que se encontravam na Seção de Documentação/Setor de Arquivo e, 


\section{|เrabaลnânecessário}

issn: $1808-799 \mathrm{X}$

ano 7 - número 9 - 2009

depois, por outras que nos foram encaminhadas pelo Setor/Laboratório de Fotografia.

Os primeiros contatos com os objetos fotográficos foram realizados pouco a pouco, de modo a captar quais eram os temas, conteúdos e o período histórico-temporal do momento fotografado. Procedemos à separação das imagens por fundo, seguindo o critério de ordem cronológica e institucional.

b) Classificação das imagens por eixo temático e espacial - Após a separação das imagens por fundo e ordem cronológica, iniciou-se uma subdivisão, separando-as por tema (diretores, professores, alunos, solenidades, etc.) e por espaço físico (fachada, laboratórios, salas de aula, pátio, etc.).

Foi na prática, a partir da separação das fotografias que se nomeou os temas e subtemas, depois, foram elaboradas as fichas de classificação e de catalogação de imagens, tendo como parâmetro, a ficha elaborada pelo Grupo de Pesquisa Memória e temporalidades da formação do cidadão produtivo emancipado.

Entrementes, a classificação das fotografias nos permitiu determinar 13 temas ou séries (diretores; professores; alunos; estrutura física; eventos; objetos; movimentos políticos; festas; visitas; concursos; servidores administrativos; rede federal de educação tecnológica; autoridades), abarcando e 158 subséries.

c) atribuição de códigos - as fotografias receberam um código expresso por um numeral que indica: o ano de sua produção, o número do álbum em que se encontram, acrescidos dos números referentes à série e subsérie e de seu número no acervo. Este código era anotado no seu verso, com lápis HB no2. Como exemplo, tomemos uma foto produzida no ano de 2003, encontrada no álbum no 10 , classificada no tema alunos, cujo número de tema/série é o $n^{\circ}$ 3. A subsérie é formada por três dígitos. O primeiro dígito é o mesmo do da série. O segundo, refere-se ao fundo e, finalmente, o terceiro indica o espaço ou a atividade da fotografia. No caso do exemplo, como são alunos do período/fundo Cefet/RJ, os dois 


\section{trabalnonecessário}

issn: $1808-799 \mathrm{X}$

ano 7 - número 9 - 2009

primeiros dígitos da subsérie são o n 3 e o nำ 5, intercalados por ponto e, o terceiro, é o $\mathrm{n}^{\circ} 1$, indicador do ambiente de sala de aula. Deste modo, a subsérie passa a ser, então: 3.5.1. E, por último, acrescenta-se o número da foto no acervo (925). Assim, o código desta foto no acervo é: $2003-10-3$ - 3.5.1. - 925

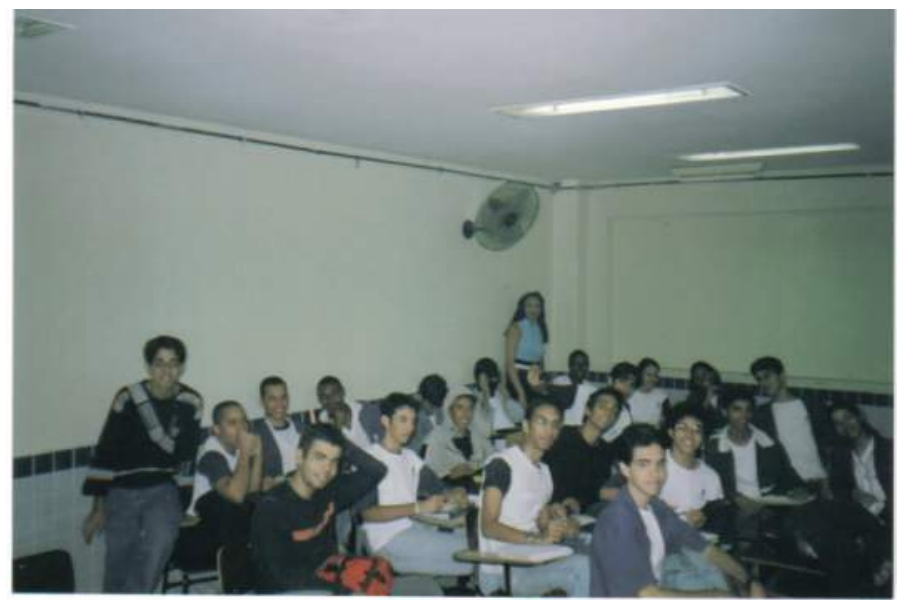

CEFET-RJ,2003, Aluno, aula de Eletricidade Básica, Prof ${ }^{\text {a }}$ Zuleide S. Silveira, turma 3AEL PIT. Acervo pessoal de Zuleide Silveira, autor não identificado.

d) identificação das fotos - $\mathrm{O}$ acervo possui nove álbuns com, aproximadamente, 400 fotografias, que foram identificadas à época de sua produção. São coleções datadas de 1937, 1942, 1951 e década de 1970. O restante do acervo encontravase, em grande parte, sem nenhuma identificação. Observamos que o olhar cuidadoso, por detrás da câmera fotográfica, buscou registrar os diversos espaços e momentos da escola. Entretanto, as fotografias ficaram guardadas em gavetas e caixas, como se "seu dono" estivesse sempre por perto para narrar a história do cenário e de atores.

e) Organização do acervo ${ }^{10}$ — Os álbuns foram numerados, seguindo o critério de ordem histórico-cronológica e institucional. Devido ao acondicionamento precário, durante anos, os mais antigos necessitam de restauração. Para o restauro do material fotográfico (capa de álbum, suporte de papel e a fotografia em si), contatamos alguns especialistas que a despeito de terem orçado o material, não chegaram a executar o trabalho por questões de ordem administartivo-financeira. 


\section{trrabalnânecessário}

issn: $1808-799 \mathrm{X}$

ano 7 - número 9 - 2009

As fotografias que estavam guardadas em caixas na Seção de documentação/Setor de Arquivo ou em gavetas do Setor de Fotografia foram arranjadas em envelopes de plásticos de polipropileno cristal liso. A cada 100 envelopes, contendo duas fotografias cada, inserimos em fichários de plástico. Estes fichários, denominados de álbuns foram numerados dando seqüência aos primeiros. Até o agosto de 2007, foram montados quatro álbuns/fichários.

\section{Considerações finais}

Marx, ao afirmar que "não é a consciência que determina a vida, mas sim a vida que determina a consciência" (MARX E ENGELS, 2002, p.20), demonstra que a integralidade da realidade social é construída pelo próprio homem, o ser social, a partir de seu ato ontológico primário - o trabalho. Portanto, são os atos ontológicos, ou ainda, é por meio do trabalho realizado individual ou coletivamente que se objetivam os campos, as forças, as instituições e as tendências histórico-sociais.

A partir desse pensamento, entendemos que um núcleo de memória é, não apenas, parte do espaço físico, parte do tempo, parte do trabalho da instituição na sua globalidade, mas também, lugar de: pesquisa em perspectiva histórica, planejar ações futuras com vista à produção e socialização do conhecimento. Por esta razão o trabalho por ele desenvolvido deve ser, gramsciniamente falando, "desinteressado".

Todo seu processo de implantação e implementação exige articular-se a um movimento maior pela participação e construção de uma escola pública, gratuita, de qualidade, única e de formação omnilateral, assumindo o caráter de lugar de memória $^{11}$ em seu triplo sentido: lugar físico de construção da memória, lugar cujo papel é preservar a memória e, lugar emblema da memória institucional.

Portanto, a memória institucional não pode ser tratada nos limites do espontaneísmo e nem depender de iniciativas isoladas. 


\section{traoalhonecessário}

issn: $1808-799 \mathrm{X}$

ano 7 - número 9 - 2009

Vale ressaltar, sob pena de ser redundante, a importância de se formar um grupo de trabalho orgânico, que se volte à implantação e implementação, de fato e de direito, de um núcleo de memória com vistas a resgatar, preservar, pesquisar e divulgar a história da instituição.

Lembramos que, o trabalho daqueles que se reúnem em torno de um núcleo de memória, não se limita às atividades arquivísticas. Enquanto, a ocupação arquivística visa à organização dos arquivos, por meio do incremento de atividades de tratamento técnico dos documentos, como avaliar, classificar, ordenar, descrever, acondicionar e programar medidas de alteração de suporte físico para a preservação e para o acesso; o núcleo de memória volta-se para pesquisas em acervo próprio e, ou, em convênio com outras instituições, com vistas a organizar e promover eventos de ordem acadêmica, como seminários, conferências, exposições, além de publicar a memória institucional em artigos, livros, e produzir documentários em meios impresso, magnético e Internet, produzindo conhecimento e socializando-o no sentido de mobilizar elementos, junto à comunidade, de reconhecimento da identidade institucional e daqueles que cotidianamente constroem a história da instituição.

\section{Notas}

1 - Doutoranda em Educação (UFF), Mestre em Educação (UFF), Professora do Curso Técnico de Segurança do Trabalho do CEFET/RJ.

2- GOETHE apud SCHAFF, 2000.

3- HALBSWACHS, 1990

4 - NORA, 1993.

5 - O CEFET-RJ teve outras denominações ao longo de sua história. Escola Normal de Artes e Ofícios Wenceslau Brás, em 1917. Escola Técnica Nacional, em 1942. No ano de 1965, passa a designar-se Escola Técnica Federal da Guanabara. Sendo que dois anos mais tarde, em homenagem póstuma ao primeiro Diretor escolhido a partir de uma lista tríplice composta pelos votos dos docentes, passa a Escola Técnica Federal Celso Suckow da Fonseca; e, em 30 de junho de 1978, é transformada em Centro Federal de Educação Tecnológica do Rio de Janeiro pela Lei no 6.545 .

6 - No início do século XX, a educação no Brasil era afeta ao Ministério dos Negócios da Agricultura, Indústria e Comércio. Em 1930, no Governo Vargas é criado o Ministério da Educação e Saúde 


\section{fraoalhonecessário}

issn: $1808-799 \mathrm{X}$

ano 7 - número 9 - 2009

Pública. A Reforma do ensino promovida nos anos de 1930 e implementada por Gustavo Capanema nos anos de 1940, deu ao ministério, a forma institucional que vigora atualmente. No entanto, em 1953, com a autonomia adquirida pela área de Saúde, surgiu o Ministério da Educação e Cultura, com a sigla MEC que permanece até os dias que correm, mesmo depois, da criação do Ministério da Cultura, em 1985, no Governo Sarney, permanecendo o desporto no MEC. Em 1995 com a criação do Ministério do Esporte, o desporto perde o vínculo com o MEC. Portanto, apesar de manter o formato institucional e a sigla MEC, as atividades desenvolvidas pelo ministério, a partir da gestão de Gustavo Capanema, foram ao longo da história, atribuídas a seis ministérios distintos: Educação, Cultura, Ciência e Tecnologia, Esportes, Saúde, Meio Ambiente.

7 - Cabe destacar que, no âmbito estadual, o Centro Estadual de Educação Tecnológica Paula e Souza (CEETPS) e o Instituto de Tecnologia da Amazônia (ITAM), vinham oferecendo desde os anos de 1969 e 1977, respectivamente, Cursos Superiores de Tecnologia.

8 - Silveira (2007).

9 - A dualidade estrutural da educação expressa na forma da lei, no Governo Cardoso, que obrigava a separação do ensino médio e do ensino técnico, torna-se mais visível, no Governo Lula da Silva, com a transformação administrativa da SEMTEC em duas secretarias: Secretaria de Educação Profissional e Tecnológica (SETEC) e Secretaria de Educação Básica (SEB).

10 - Cabe registrar nosso agradecimento ao ex-estagiário Mário Jorge Barretto, por sua dedicação, o que contribuiu, significativamente, nos processos de codificação, identificação e organização do acervo fotográfico, como também, ao ex-estagiário André Gatto, aluno do ensino médio, que, com afinco, deu continuidade ao trabalho iniciado por Mário Barreto; e, ainda, agradecemos ao exestagiário Rafael Rodrigo S. Ferreira por seu empenho na informatização de dados, digitalização do acervo e, em especial, pela transposição da ficha de classificação e catalogação de imagens para o programa de banco de dados.

11 - Nora (1993).

\section{Referências bibliográficas}

BRASIL. MEC. BRASIL. Lei no 6.545, de 30 de junho de 1978. Dispõe sobre a transformação das Escolas Técnicas Federais de Minas Gerais, do Paraná e Celso Suckow da Fonseca em Centros Federais de Educação Tecnológica, e dá outras providências. Brasília, 1978.

. Lei de Diretrizes e Bases da Educação Nacional. Lei no 9.394, de 20 de dezembro de 1996. Brasília, Brasil.

Decreto. Decreto no 2.208, de 17 de abril de 1997: Regulamenta a educação Profissional.

. Portaria. Portaria no 646 de 14 de maio de 1997: regulamenta a implantação do disposto nos artigos 39 a 42 da Lei n-9394/96 e no Decreto no 2.208/97.

. Portaria. Portaria no 1005, de 10 de setembro de 1997: Institui no âmbito da SEMTEC a Unidade de Coordenação do Programa de Reforma da Educação profissional (PROEP). 


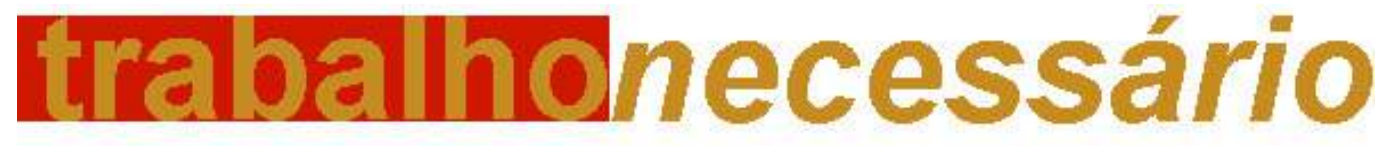

issn: $1808-799 \mathrm{X}$

ano 7 - número 9 - 2009

. Decreto. Decreto o 5.154, de 23 de julho de 2004: Regulamenta a educação Profissional; revoga o Decreto n 2.208/97.

CARDOSO, Ciro Flamarion. Um historiador fala de teoria e metodologia: ensaios. Bauru, São Paulo: EDUSC, 2005.

CIAVATTA, Maria. Educando o trabalhador da grande 'família da fábrica": a fotografia como fonte histórica. In: CIAVATTA, Maria; ALVES, Nilda(Orgs). A leitura de imagens na pesquisa social: história, comunicação e educação. São paulo: Cortez, 2004.

A formação integrada: a escola e o trabalho como lugares de memória. In: FRIGOTTO, Gaudêncio; CIAVATTA, Maria e RAMOS; Marise. Ensino médio integrado: concepções contradições. São Paulo: Cortez, 2005.

; CAMPELLO, Ana Margarida. Do discurso à imagem - fragmentos da história fotográfica da reforma do ensino médio técnico no CEFET Química. In: FRIGOTTO Gaudêncio; CIAVATTA, Maria. A formação do cidadão produtivo: a cultura de mercado no ensino médio técnico.

DIAS, Demóstenes de Oliveira. Estudo documentário e histórico sobre a Escola Técnica Federal "Celso Suckow da Fonseca". Rio de Janeiro: Setor de Artes Gráficas do CEFET/RJ; 1980.

FONSECA, Celso Suckow. História do ensino industrial no Brasil. Rio de Janeiro: Tipografia da ETN, 1961.

HALBWACHS, Maurice. A memória coletiva. São Paulo: Vértice Editora. 1990.

MARX, Karl; ENGELS, Freidrich. A Ideologia Alemã. São paulo: Martins Fontes, 2002.

MAUAD, Ana Maria. Fotografia e história - possibilidades de análise. In:

CIAVATTA, Maria; ALVES, Nilda (Orgs). A leitura de imagens na pesquisa social: história, comunicação e educação. São paulo: Cortez, 2004.

NORA, Pierre. Entre memória e história: a problemática dos lugares. Revista do Programa de Estudos Pós-graduados em História e do Departamento de História. São Paulo: Projeto História, o10, dezembro de 1993.

PROJETO do Centro de Memória do CEFET/RJ. Portaria da Direção Geral, n. 008 de 5 de janeiro de 2006.

SCHAFF, Adam. História e verdade. 3. Ed. Lisboa: Editorial Estampa, 2000.

SILVEIRA, Zuleide Simas da. Projeto político-pedagógico: a busca da identidade. In: Tecnologia \& Cultura. Revista do Centro Federal de Educação Tecnológica Celso Suckow da Fonseca. Ano 6, o 6, jul./dez. 2004. Rio de Janeiro: CEFET/RJ, 2004. 


\section{frabalnonecessário}

issn: $1808-799 \mathrm{X}$

ano 7 - número 9 - 2009

Contradições entre capital e trabalho: concepções de educação tecnológica na reforma do ensino médio e técnico. Dissertação (Mestrado em Educação) Universidade Federal Fluminense, Niterói, Rio de Janeiro, 2007. Disponível em: http://www.uff.br/pos educacao/joomla/images/stories/Teses/zuleidesilveira07.pdf. 